\title{
Comparative Study on the Characteristics of Community-Based Tourism between Pentingsari and Nglanggeran Tourism Village, Special Region Yogyakarta
}

\author{
Novia Purbasari $^{1}$, Asnawi Manaf ${ }^{2}$ \\ ${ }^{1}$ Research Assistant in Urban Development Laboratory, Urban and Regional Planning Department, Diponegoro University- Semarang- \\ Indonesia. \\ ${ }^{2}$ Senior Researcher in Urban Development Laboratory, Urban and Regional Planning Department, Diponegoro Univers ity - Semarang- \\ Indonesia,
}

\begin{abstract}
Community-based tourism is one of the tourism development models that effectively used as a tool to alleviate poverty through empowerment strategy of the local community. Nevertheless, many people do not have adequate understanding on the characteristics of community-based tourism, which are used as a determinant in the tourism development. This article describes the comparison on characteristics of community-based tourism between Pentingsari and Nglanggeran. These villages were chosen because Pentingsari was a tourism village that able to apply the principles ethical codes of world tourism, shown by an award from the World Committee on Tourism Ethics Code and Nglanggeran was awarded as Best Tourism Village award in Indonesia from ASEAN Community Based Tourism Award 2017. The objectives of this study is to explore the characteristics of community-based tourism applied in the Pentingsari and Nglanggeran, and to identify any indicators that could be used to indicate those characteristics. The research achieves through in-depth interviews, observation, and review of documents. There were 17 persons as informants. Further, the observation was reached by directly observing in the both study cases. In addition, the data obtained through the review of secondary data from the local manager of tourism village. Generally, Pentingsari has characteristics as a community-based rural tourism, while Nglanggeran has characteristics as community-based ecotourism.
\end{abstract}

\section{Introduction}

Development of rural tourism in Indonesia is able to move other sectors and give impacts on rural economies in general and specifically to involve the communities. It is related to the role of rural tourism capable to creating jobs, improving the living conditions of rural communities and moving the creative economic activities of rural communities. "Tourism may be highly relevant to slow down the loss of biodiversity through the planning and management of protected areas for improvements as foster local participation" [7]. "Rural tourism has a value of exploiting social environment, preservation of culture, and the spirit local empowerment" [6]. One development of tourism activities performed in the form of community-based tourism, which can be managed by community with simple management. "Community Based Tourism is an opportunity to move all the potential and dynamics of society, in order to balance the role of large-scale tourism businesses. This is because the community empowerment in community based tourism is able to give community an opportunity to build social capital which is defined to sharing profits as a result of tourism activities which are ran together. Community based tourism does not mean only small and local efforts, but should be placed in the context of global public partnership" [5]. Nevertheless, many people do not have the adequate understanding of the characteristics of community-based tourism, due to community-based tourism is depended on different geographical conditions around the world. "This created a different way to look for alternative traditional mass tourism, and it created a destination creations possible providing welfare for local communities and creation of jobs" [8]. Many characteristics of community-based tourism can't be appropriately applied to the Tourism Village, considering the community-based tourism is one approach that emphasizes empowerment tourism.

This article described the results of qualitative study using two cases study about the characteristics of community based tourism. It was taken at Nglanggeran and Pentingsari Tourism Villages. Both Tourism Village were located in Special Region of Yogyakarta. "Special Region of Yogyakarta was a province that second ranked after Bali in terms of tourism potential. This was because

Corresponding author: veapurbasari@gmail.com 
the Special Region of Yogyakarta had diversity of object factors and the object with a variety of specifications steady and unique character" [9]. Both tourism villages were used as cases study because through community based tourism Nglanggeran Tourism Village been successful in conservation efforts, while Pentingsari Tourism Village has succeeded in the conservation of cultural and empowerment of local communities. Some awards have also been achieved Nglanggeran Tourism Village one of them is "Cipta Award 2011 in the management of Natural Tourism Attractions insightful Environment National Level [10]'. While Pentingsari Tourism Village was a village that be successful as a tourism village that able to apply the principles ethical codes of world tourism, including the application of empowering local communities. This was shown by an award from the World Committee on Tourism Ethics Code. Both Tourism Village have different characteristics concept. Therefore, through this study, later with both of these case studies, will be compared to understand both community based tourism's characteristics. The uniqueness of this study compared to studies that have been done are indicators that can be used to identify the characteristics of community based tourism.

\section{Literatures}

\subsection{Tourism and tourism system}

"Tourism is the activities of the people who travelling and living in places outside of their usual environment for not more than one consecutive year for leisure, business, and other purposes. Environmental usual term meant to exclude the trip in ordinary residential areas, frequency and regular trips between domicile and place of work, and other community trips routine [4]. "Tourism is also a process, activities and results that arise from the relationship and interaction among tourists, tourism suppliers, local authorities, host communities, and the environments are involved in attracting and hosting visitors [4]. Activities occurring in tourism [4] as follows: Tourism is an activity trip or tourist movements from place tourist stay to tourist destinations. Tourism is also always involves the fulfillment of goods and tourist services which far from their place. Tourism is an activity enjoyed attractiveness provided by the attractions and also involves the interaction between tourists as visitors with communities living on tourism.

Definition of tourist is every person who traveling to a place from their daily environment in a period of less than one year (12 months) to perform an activity and contributing to the places visited. Tourist also can be defined everyone traveling between two or more countries or between two or more areas within / usual residence country. All types of travelers in tourism are described as a visitor, a term that is the basic concept from entire system of tourism statistics. International visitors are people who travel for a period of not more from twelve months to another country from which in which they often live and whose main purpose is other than the implementation of income in the place visited. Internal visitors are people who travel to a destination in their own country, which is outside their usual environment, for a period of not more from twelve months [4]. In addition, the tourism system also consists from the elements of tourism [15], namely: Main, which appeal being a trigger tourism activities and the population as tourism actors and the host tourism; Prerequisite, which transportation for ongoing process of tourism; Supporting, which information and promotions to build and encourage interest traveled; Support services that tourism element which makes the process of tourism activity becomes easier, comfortable, secure and enjoyable such as hotels, guesthouses and others.

\subsection{Community based tourism}

Community based tourism generally is a small scale tourist activity and involves the interaction between visitors and the local community, particularly suited for rural areas. CBT is understood to be managed and owned by the community, for the community. It is a form of 'local' tourism, supporting local service providers and suppliers and focused on interpreting and communicating the local culture and environment [1]. The definition of community based tourism is tourism that prioritizes environmental sustainability, social and cultural rights in the account. It is managed and owned by the community, for the community, with the purpose of enabling visitors to increase their awareness and learn about the community and the local way of life [14]. While different opinion that "community based tourism is tourism which realize continuity of cultural, social and environmental. This form of tourism is managed and owned by the community in order to help tourists raise their awareness and learn about the way of life of local communities. It has a different concept of mass tourism. It is a model of tourism development which assumes that tourism must start from the awareness of values the needs of society in an effort to build tourism which is more beneficial to the needs, initiatives and opportunities for local communities [9]. It based on the active participation from local communities this makes the creation of a community can support this type of tourism. While at the same time it can also create relationship between the local community and visitors [8].

The principles that can be used as a tool of community development for local communities [9], namely: recognize, support and promote communityowned tourism; involve community members from the beginning in every aspect; promotes community pride; Improving the quality of life; ensure environmental sustainability; maintaining the character and the unique local culture; helping to develop cross-cultural learning; Respecting cultural differences and human dignity; distribute benefits equitably among community members; and to contribute a percentage determined for income community projects. 
In addition the above, other matters relating to Community Based Tourism is a measure of the success criteria for Community Based Tourism obtained through evaluation research in several countries in Asia [11]: involving mass of people; benefits can be distributed equitably to all communities; good tourism management; strong partnerships both inside and outside; unique attractions; environmental conservation has not gone unheeded. Related to that, Prabawati has identified the success factors Community Based Tourism [11], among others: the uniqueness of the location; facilitation of funding for embryos existing activities; extensive community involvement as tourism actors; figures mover; and links.

Community Based Ecotourism is a form of ecotourism which emphasizes the development local communities; allowing for local residents to have great control over; involvement in development and management; and a large proportion of the benefits remain within the community. Community Based Ecotourism should encourage sustainable use and collective responsibility, but also include individual initiatives within the community [3]. Furthermore, Community Based Ecotourism implies that people take care of the natural resources in the context of income earning through the operation of tourism enterprises and use it income to improve the lives of its members. Therefore, CBE involves conservation, businesses enterprise, and community development [13].

\section{Research methods}

This study used qualitative approach and case study strategy with multiple case studies type [2] because researchers explored the differences of both case and the results depicted in the comparison of characteristics. Research of both case studies resulted in two community sustainability lessons learned from the two characteristics of the different community based tourism and some indicators that can be used to indicate the characteristics.

The unit of analysis was a case study of the characteristics of typology community based tourism. In this case the informant acted as a resource. Determination of informants in this study used purposive and snowball strategy. Purposive method was performed by interviews of government agencies while the first informant acted as keeper gathering. Besides, the snowball method was performed by the determination of community informants. The role of researchers in this study was as a key instrument, where researchers collected their own data through documentation, behavioral observation and interviews with participants

Analyses were performed by using the analysis techniques of qualitative descriptive. The analysis was began by identifying characteristics of both tourisms and comparing characteristics of each typology that resulted in two different characteristics and indicators that could be used as a tool indicate it.

\section{Result and discussion}

This article aimed to explore the understanding of the characteristics of community based tourism that was applied in the tourism village, as well as identifying any indicators that could be used to indicate those characteristics. This analysis performed at Nglanggeran and Pentingsari Tourism Village. The findings of indicators characteristic community based-tourism reference to success criteria of community-based tourism [11] and the success factors of community-based tourism [11]. Criteria and these factors were taken with naturalistic in the field conditions just for structuring in order to obtain indicators of community-based tourism characteristics. Below are the findings of research related to community-based tourism in Nglanggeran and Pentingsari Tourism Village.

\subsection{Coverage area}

Nglanggeran Tourism Village has covered by one administration area, which involving the residents from five hamlets to be a tourism community. Meanwhile, Pentingsari Tourism Village covered one hamlet area which involving the whole residents of Hamlet. The differences between those covered areas, affect the form of intervention by other parties, the government in particular, because of direct relevance to the territory authorities. The village government in Nglanggeran contributes to tourism activities, due to the management of tourism managed by Pokdarwis (organization under BUMDes/village-owned enterprises). Different from Nglanggeran, Pentingsari Tourism Village just has the one hamlet of coverage area, can stand independently without involves village government in the management of the tourism.

\subsection{Concept and form of attraction}

Tourism attractions in Nglanggeran Tourism Village are the attraction of the initial appearance of the appeal (the natural attractions) in the form of "Gunung Api Purba" [12] and evolve over time raising other attractions. Other nature attractions are "Kedung Kandang" waterfalls located around the area of Nglanggeran Village Tourism. Besides nature, there is also a tourist attraction that utilizes artificial natural potential. One of the most interesting is "embung" of fruit made reservoirs to irrigate the orchards, but presents a beautiful view. In addition, there are also points of outbound around "Gunung Api Purba", whether it's flying fox, raffling, and climbing. Everything was based nature "Gunung Api Purba" that serves a wonderful view. There is also spa tourism, the relaxation sensation supported by a village atmosphere that makes tourist become more relaxed. Other attractions are the educational and cultural travel that is presented in the form of tour packages such as travel packages agriculture, live in, local arts, culture, love of nature, and culinary. It is like what has been described by the facilitator Nglanggeran Village Tourism: 
"... firstly "Gunung Api Purba", but now there are three destinations of the first "Gunung Api Purba", "Embung Buah" Nglanggeran; and "Kedung Kandang" Waterfall... we are also a village tour that sells educational packages, So we have agriculture, animal husbandry, there is also culture and art, then the third is the adventure attraction, we provide many packages of adventure activities option as well, there are raffling there is rock climbing, then outbound..." (SH,W1A,28-04-2016, 4-13)

Attractions in Pentingsari Tourism Village are combine of creativities and local wisdom that supported by the nature potential in valley of Merapi Mountain, which rarely found in other places [12]. Community still upholds the local wisdom, and this is attract for visitors, especially for live-in activity. The attractions that presented in here, can not be enjoyed only in one part. However, it must be enjoyed as travel package. This make the length of the visitors staying become longer. Tourist attractions are packed in many packages, in addition to the natural attractions and local wisdom life is also an educational and cultural. Tourists can learn about art, culture, farm life, the arts, mushroom cultivation, processing food, travel bulbs (about variety of bulbs and other dairy products), etc. In addition, there are some historical relics which can be used as historical knowledge. For visitors who love to camping, Pentingsari Tourism Village also provides camping ground that can be used as place for camping. Tourist attractions which will serve as the main magnet to attract tourists to come and visit the tourist village. Overall tourist attraction developed by the communities themselves through the tourist village board, whose members come from the community itself. Here are excerpts of interviews related to it:

\begin{abstract}
"Attractions are combination of physical village with creativity, not art but the creativity of residents in performing art, in farming, in social activities. It is the attraction with the physical village which is the environment is the village environment, well that there will be homestay accommodation, that's the attraction, $\mathrm{Nah}$, if people stay that hotel is a standard, if staying in the homestay is an attraction that combines the physical village is interesting, tracking people are also interesting, it's also an attraction. "(DY,W2B,10-05-2016,3-10)
\end{abstract}

The concept of attraction on both the Tourism Village affects to the length of the visitors staying. The attractions of conservation in Nglanggeran Tourism Village give choice to visit in a short time (less than one day) or visit in a long time (live in that take more than one day). While the concept of the attractions presented Pentingsari Tourism Village, visitors must make a visit in a long time (more than one day) to enjoy the attractions offered by the package.

\subsection{Tourism actors and community involvement}

Nglanggeran Tourism Village involved the community as subjects and objects of tourism activities. They entered the groups of homestay providers, providers of culinary, tour guides, art activists, agricultural activists, and organizer of tourism activities. Besides being the actors, community also becomes the direct beneficiaries of tourism activities expressed through the interview excerpts below:

"Our communities makes the first and main beneficiaries, because our area is ecotourism, community-based environmental insight, so the community will be the perpetrators"(SH,W1A,28-04-2016,75-78).

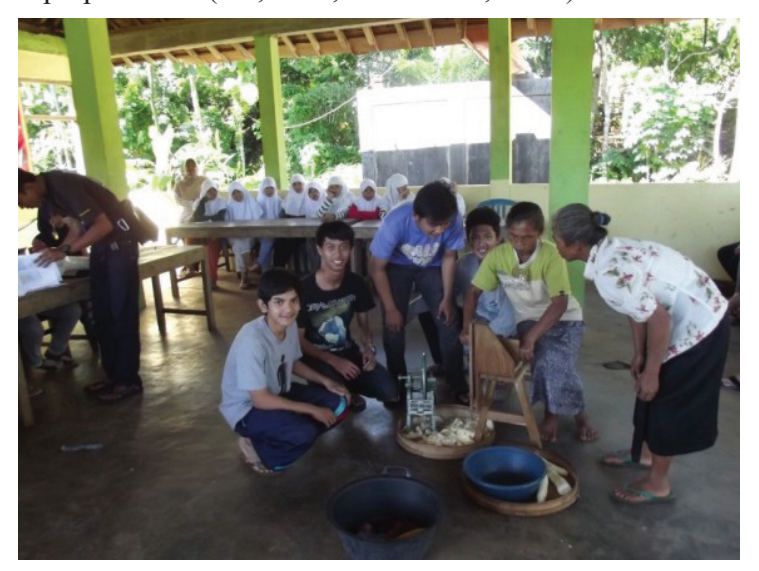

Fig. 1. Involvement Farmers Group And Culinary Groups In Nglanggeran Tourism Village

Source: Documentation Pokdarwis Nglanggeran, 2014.

The community also involved in monitoring and evaluation activities of the Tourism Village to interact with the tourists directly. It is also directly related to the decision-making in the management and development of tourism village. It through the forum meetings are held every "Malam Selasa Kliwon" (Tuesday Kliwon Night in Javanesse calendar) involving Podarwis, community and local village government. Here are excerpts of interviews with the Chairman of the Youth:

\footnotetext{
"The role, function and community involvement more to decision-making, monitoring and evaluation, providing input and so on. We have a forum called "Malam Selasa Kliwon ...." (AB,W8A,9-05-2016,98-112).
}

Community involvement applied in Pentingsari Tourism Village is the involvement of the community directly as a subject in every aspect of tourism activities as well as objects that attract tourists. Communities participate in the management, planning, development undertaken by the village board tourism, while regarded as an object, as a tourist attraction from all over the community activities and community life. Community also serves as direct beneficiaries, as tourism activities in Pentingsari Tourism Village is an activity undertaken of the people, by the people and for the people. Forms of community involvement in tourism activities are to be homestay provider, the provider of the attractions done by farmer groups and arts, then there is the PKK, which acts as a provider of culinary and souvenirs, youth also had a role as tour guides. The involvement contributes greatly to the development of rural tourism. Pentingsari Tourism Village able to get an appreciation of the 
Committee on Tourism Ethics Code of the World (World Committee on Tourism Ethics - WCTE) as a tourist village that is able to apply the principles of the Code of Ethics for Tourism of the World, including the implementation of efforts to empower local communities or community-based tourism. Here are excerpts of interviews related to it:

"... They can contribute with their own abilities. I have a homestay, it means they will be involved as a homestay owner of 60 families, then their involvement in culinary and consumption, yes they have women's groups, PKK. Continue, involvement in attractions, agriculture-based, cultural-based, nature-based attractions, it's got people too. So they donate and contribute according to their own character. "(DY,W2B,10-05-2016,70-79)



Fig.2. Involving PKK as Culinary Group In Pentingsari Tourism Village

Source: Documentation Authors, 2016.

\subsection{Initiator community-based tourism}

The initiation of Nglanggeran village as one of tourism destinations came from activities of communities to conserve nature through conservation efforts due to the environmental degradation associated with the availability of water. However, as the natural potential has been welcoming visitors solely for camping, people were initiated to develop it into a tourism activity particularly when "Karang Taruna" (youth organization) began to follow the race in the field of conservation. Achievement gained increasingly spur communities to develop tourism activities. Here are excerpts of interviews related to it:

" We set out from youth activities, our background is more to conservation activities .... "( $\mathrm{AB}, \mathrm{W} 8 \mathrm{~A}, 9-05-$ 2016,127-128)

Pentingsari Tourism Village emerged from the local people without the intervention of any party. It started from discussion conducted by several prominent people. They saw the rural potential and local knowledge which were rare found in this modern era. Seeing the needs of urban communities about the sense of comfort village, the idea to developing Pentingsari came as a tourist destination that sells life and village atmosphere. This initiation came up with preparing the the initial program and the next steps. After consideration, the results of these community leaders conveyed to the Pentingsari's residents through deliberation as well. According to the agreement of these deliberations, Pentingsari prepared and opened as tourism activities. Sleman District Government through the Department of Tourism provided the guidance when it was opened. Here are excerpts of interviews related to it:

"... In the beginning it was from Mr. Sumardi, Mr. Ajun, Mr. Toni Sukoyo, all the time since it was the pioneer or the initiator of the Tourism Village, they continued to my place. Automatically even though it was initiated like that, if there is no public support, it certainly is not there ... "(R, W7B, 13-05-2016,39-43)

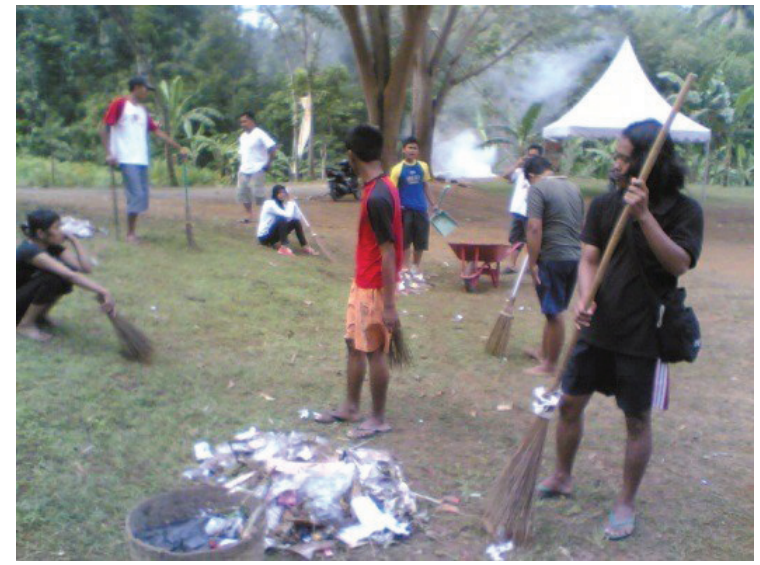

Fig. 3. Initiation of Tourism Activity Starts From Conservation Activity in Nglanggeran Tourism Village

Source: Documentation Pokdarwis Nglanggeran Tourism Village, 2016.

\subsection{Tourism asset ownership}

Tourism assets are important for the ongoing tourism activities. Ownership status of tourism assets affects the tourism activities related to land ownership, ownership of tourist facilities and tourist activities. Land ownership in tourism activities at Nglanggeran Tourism Village belongs to the people at the homestay and some land for tourist activity, and local government. Besides, the land of 48 ha around "Gunung Api Purba" is "Sultan Ground" owned by the Sultan lent to the local government via "Right to Wear" through "PANITIKESMO", this right was submitted to Pokdarwis for managed, maintained and used towards public welfare. Facilities in tourism activities belong to the peoples who through Pokdarwis managed and maintained for tourist activities. They are also the owner of tourism activities. The peoples are the subject and object in travel are the key passage of a tourist activities in the Tourism Village Nglanggeran. The peoples as the subject and object in tourism are the key passage of tourism activities in the Nglanggeran Tourism Village. Some of the villages owned assets and the government-owned assets (Sultan) then Pokdarwis formed are under BUMDes (Village-owned enterprises) Nglanggeran. Here are excerpts of interviews related to it:

"... if for the ownership of the land itself mostly especially for this "Gunung Api Purba" area belonging to Sultan's 
Ground, but some also belong to the citizens, and also the residents themselves make some facilities for our activities, so We are working with the community to provide facilities ..."

The land of Pentingsari was almost owned by community, it used as homestay and other tourism activities. The land used as a camping ground is an area of land the village treasury is deliberately hired by Pentingsari Community Tourism at the lower cost than the rent cost elsewhere. Here are excerpts of interviews related to it:

"...mostly belonging to the community, but the camping belongs to the village treasury ..." ..." (S,W1B,10-052016,67-68)

Ownership of tourism activities also one part of the tourism assets that affect tourism activities in Pentingsari Tourism Village. Tourism Activities in Pentingsari Tourism Village are all owned by the community, run by the community and its benefits to the community.

\subsection{Tourism management and decision making}

Management of both Tourism Villages have brought success in community empowerment. Here are some form of managements found at the both Tourism Villages:

\subsubsection{Management of tourism}

Management of tourism activities in Nglanggeran Tourism Village is semi-modern management of "social enterprise management." The management of tourism activities was monitored, reported to the community. Public also control of tourism activities. The social principle is also becoming one of the basic as well as its governance over to the local knowledge grew in society. However, to increase the capacity of human resource people do enterprise systems (Semi modern) in which each party involved in tourism activities, using a promissory note agreement, so that if the party violates the agreement, there will be a warning in accordance with a written agreement. Besides the use of technology is also used in the management of tourism, one of them with their e-ticketing are connected directly to the intranet manager. Here are excerpts of interviews related to it:

"Our management is more to the management can be called the management of a company, but you can call it as a social company." (AB,W8A,9-05-2016,161-164).

Tourism management in Pentingsari Tourism Village managed based on the benefits. All forms and management activities carried out by the community with the principle of high familial and social capital. The management was done from the community, by the community, and for the community. Local wisdom in Pentingsari still very thick felt, it seen from the social capital invested community towards tourism activities itself. Moreover, the manager of Pentingsari Tourism Village also does the bookkeeping and management in a transparent manner with a known and through community meetings decision. Here are excerpts of interviews related to it:

" We managing tourism activities based on benefit. So we managing it together, we counting it together and we enjoying it together. So who contribute will get the benefit, who have not contributed, we encourage them to contribute ... "(DY, W2B, 10-05-2016,93-97)

\subsubsection{Organization of Tourism Management}

Management of Nglanggeran Tourism Village is managed by the community, through organizations formed under BUMDes (Village-owned enterprises) Nglanggeran, namely Pokdarwis. Pokdarwis (Travel Awareness Group) of Nglanggeran Village Tourism Village is a management organization established by the Government Nglanggeran as a business community for management forms of Pokdarwis are shown as follows:

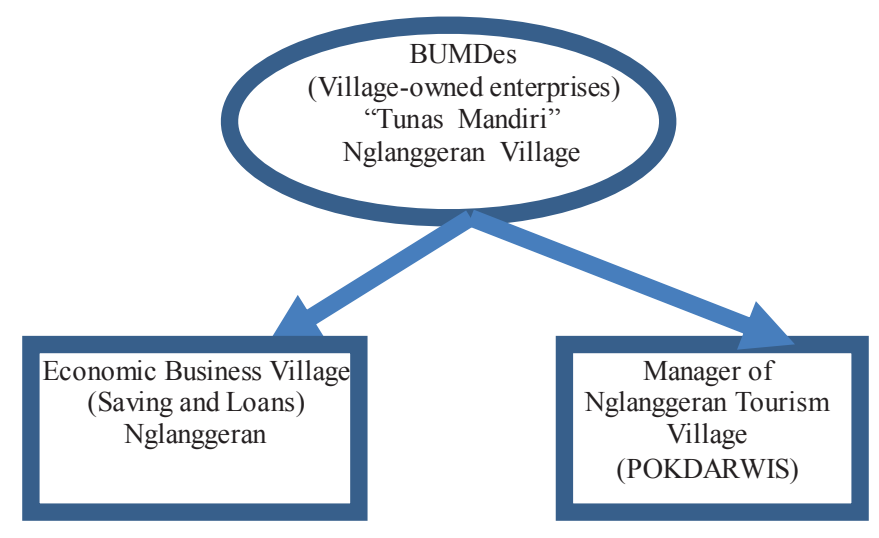

Fig. 4. Pokdarwis Position In The Nglanggeran Tourism Village

Source: Pokdarwis Nglanggeran, 2014.

Pentingsari Tourism Village also has management organization. The management is not managed by the local government but managed by the village board tourism. This Tourism Village board still traditionally have come from communities that are social. In this management are the division of tasks according to predefined positions, but their position remains the same as the board equally from the public and social nature. Here are excerpts of interviews related to it:

\section{"... The important thing is we have a board, the Tourism Village organization is everything were set up." (N,W5B, 11-05-2016,62-63).}

Tourism Village Board is to manage based on fields that have been distributed according to their respective capabilities. All involved were local residents, it is because this management still a social group in society. 


\subsection{3 legality of management}

Legality manager is one of the important issues related to the legal status and certainty in the management of tourism activities. Legality manager in Nglanggeran Tourism Village can be seen from the Decree of the Head of Village Nglanggeran given to Pokdarwis Nglanggeran to manage and develop the Tourism Village. The status of Pokdarwis is under BUMDES Nglanggeran, where there is accountability reports and the distribution portion of the proceeds from tourism village for public welfare, as expressed in the interview excerpts below:

".. we as village Government establish BUMDes that have a legal entity, it overshadow tourism activities, including Pokdarwis, village level micro-finance activities......we make Decree related to POKDARWIS, include in relation to cooperation with the implementation of contribution from the local government ... "(S, W4A, 2-05-2016,52-58)

Management status of Pentingsari is registered by the Culture and Tourism Office of Sleman. This Tourism Village do not have legality as Pokdarwis, because it is given at the Tourism Village coverage administrative territory of the village, while the Pentingsari Tourism Village is just one hamlet. With the existence of this registered status, indicating that Pentingsari Tourism Village is one that is accompanied by the Culture and Tourism Office of Sleman. There is not a full government intervention in its management. For institutional and managers all remain in the hands of the population, while the government is only acting as a company. Here are excerpts of interviews related to it:

"We only registered, so it is recorded in the Tourism Office...." (DY,W2B,10-05-2016,106-108)

\subsubsection{Sharing profit system and levy}

Related to the legal status manager Tourism Village Nglanggeran under BUMDES, it affects to their profitsharing system. This revenue sharing profit system do Pokdarwis to the village, so that approximately $10-15 \%$ of cash coming into the village. Although basically the village government is not demanding and requires a system for these results, but for the welfare of the whole society Nglanggeran, then the sharing system is held, for cash village itself is used for the construction of public facilities for the community. Here are excerpts of interviews related to it:

"... if for our local village government there is income of $10-15 \%$ every month.... “(AB,W8A,9-05-2016,423-428)

Nglanggeran Tourism Village is one that implements the withdrawal of levies such as those contained in Gunung Kidul District Regulation No.17 Year 2013. It is intended as an umbrella law at the Tourism Village Tourism activities Nglanggeran. Withdrawal fees are due at the Tourism Village Nglanggeran there are a few attractions. However, for the withdrawal of these levies through the door with entrance tickets are serviced by Pokdarwis. Amount of levy to be paid visitors amounted to IDR 2000.00 per month and the levy paid to the local government as the PAD village. Will be refunded by $35 \%$ and from village $\mathrm{PAD}$ will return to Pokdarwis by $60 \%$ as operating costs. Here are excerpts of interviews related to it:

\begin{abstract}
"Meanwhile, if the local government there is a share of 2000 rupiah per tourist in the form of retribution every month to City. Then, there is a return to us $35 \%$. So the nominal 2000 rupiah goes to the PAD of the Village, and from the PAD Village, $60 \%$ of it will return to us for operational costs. "(AB, W8A, 9-05-2016,428-432).
\end{abstract}

Profit-sharing system and the withdrawal of the levy do not apply in Pentingsari Tourism Village due to the influence of local government policy. This shows that the community plays its full course of tourism activities, while government intervention does not dominate.

\subsubsection{Monitoring, evaluation and networking aspirations}

Tourism management in Nglanggeran has their whole local people as the Pokdarwis workers. In order to monitor and evaluate the performance of Pokdarwis, every "Malam Selasa Kliwon" (Tuesday Kliwon Night in Javanesse calendar) they have a meeting in which discusses all the problems, obstacles, and being a vessel performance of public aspirations. The meeting is attended by all tourism stakeholders, community leaders and local government (village government). This activity is very positive, as it can quickly find the solutions of the problems and monitor the performance of all actors in Nglanggeran. Here are excerpts of interviews related to it:

"We have a forum called "Malam Selasa Kliwon", so every Tuesday Kliwon is our meeting from Pokdarwis, the village government, community leaders submit the work program, then accept the aspirations of the community in the form of criticism and constructive suggestions. Well later in a forum that arose agreement. Well that agreement is what we will use. "(AB, W8A, 9-05-2016,100-105)

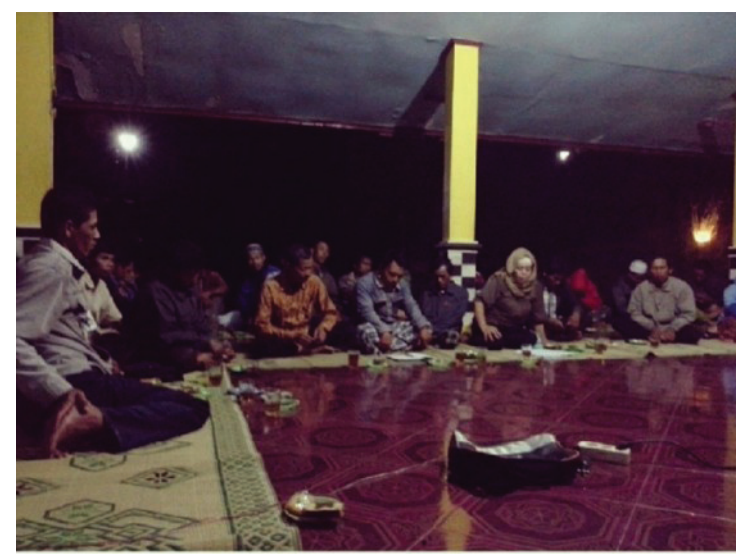

Fig. 5 "Malam Selasa Kliwon" Meeting as Monitoring and Evaluation Activities In Nglanggeran Tourism Village Source: Documentation Pokdarwis Nglanggeran Tourism Village, 2016. 
To perform monitoring and evaluation of tourism activity, it is done in consultation with the meeting. This meeting was held at fixed times, even if it is necessary to discuss something, then the meeting is held. All decisions are in the hands of the community. Therefore, in the monitoring and evaluation, community plays a fairly big in decision-making. Here are excerpts of interviews related to it:

"... all rights belong to the community. We only carry out the tasks of the people's decisions. So if you want to make a chairman ... "(S, W1B, 10-05-2016,70-73)

\subsection{Concept of tourism}

The concept of tourism departs from the vision and mission of the establishment of the Tourism Village. Tourism Village Nglanggeran vision is: "Tourism Village being featured with environmentally friendly ecotourism and community based." To realize this vision, Pokdarwis Nglanggeran develop a mission as follows:

- Protecting the environment in the area of " Gunung Api Purba" Ecotourism, good culture, flora, fauna and also the uniqueness of rock.

- Engage communities as actors and managers of Village Tourism and "Gunung Api Purba" Ecotourism Area Nglanggeran.

- Improve long-stay travelers (length of stay) in the district of Gunung Kidul and DIY

- Improve public welfare

Concept of tourism development in the area of Nglanggeran Village Tourism is an ecotourism concept that manages the potential for the welfare of society while still promoting the principle of conservation of nature, culture, flora and fauna as well as other potential. If classified in the concept of travel, the Tourism Village Tourism Village Nglanggeran is implementing the concept of community based eco-tourism. See the main purpose as conservation activities, but also did not rule out the needs of the economy and the welfare of society. In addition the development is done through empowerment of local communities, so that local communities grow as an independent community. As disclosed in the interview excerpts below:

"..., finally they also read the potential there, to save the existing conservation and then packed into attractions." (M, W5A, 2-05-2016, 82-85)

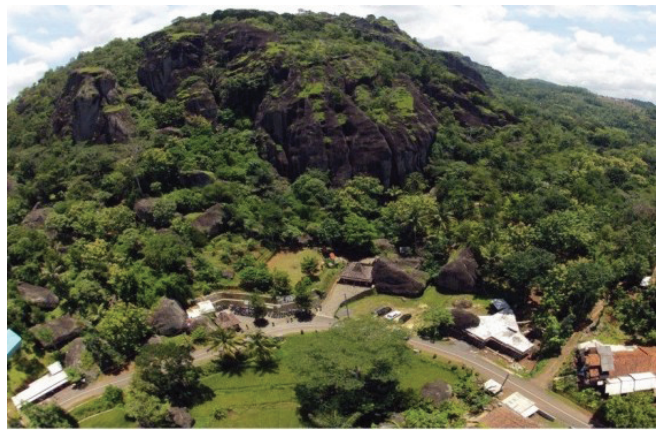

Fig. 6. Concept of Community Based Eco-Tourism In Nglanggeran Tourism Village

Source: Documentation Pokdarwis Village Nglanggeran, 2014.

Pentingsari Tourism Village has concept lift local wisdom as a reference for the presentation and development of tourism activities in the Pentingsari Tourism Village. Took away result of community creations combined with the rural atmosphere and local wisdom of rural communities, directing the Tourism Village Pentingsari grown into a tourist destination to apply the concept of community-based rural tourism. This is evident from the efforts of local people serving life atmosphere of the village with the principles of community empowerment. As we can see in the following interview excerpt:

"... combining the physical village with the creativity, not the art but the creativity of community in performing art, in farming, in social activities, it's the attraction with the physical village which is the environment is the village environment." (DY, W2B, 10-05- 2016,2-7)
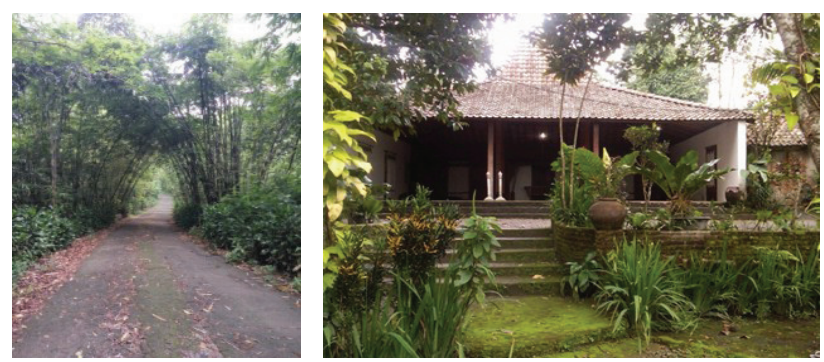

Fig. 7 Concept Of Community-Based Rural Tourism In Pentingsari Tourism Village

Source: Documentation Authors, 2016

\subsection{Comparison of characteristics both community based tourism}

From the description of the characteristics of both the Tourism Village above, in outline, comparison of characteristics between both Community-Based Tourism are as follows: 







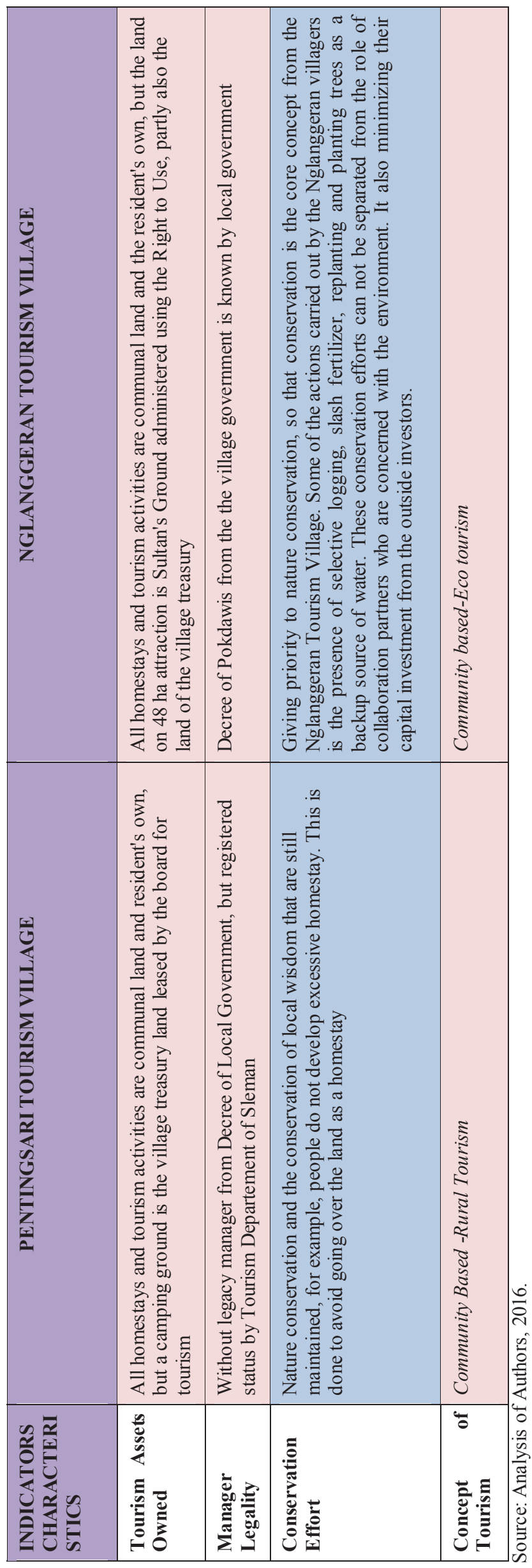


Table above shows several similarities and differences of the characteristics in both Tourism Villages. Similarities characteristics are shown by tourism actors, community involvement and the role of the community. Besides, the differences characteristics are shown by covered area; Nglanggeran covers one village and Pentingsari covers one hamlet. This is certainly an impact on collaborations and role of local government. Additionally there are other differences in the form and the main attractions are presented. For Nglanggeran Tourism Village, in addition to the lives of people who become attractions, the existence of three objects that are part from the Gunungsewu geopark be one part of the attraction. For the management of tourism, Pentingsari Tourism Village more on traditional management with communities as a manager through the Tourism Village board whose status is registered by the Tourism Office of Sleman and profit used for the construction of public facilities, some are also distributed to the community. While the Nglanggeran Tourism Village management is the management of social entrepreneurs conducted by Pokdarwis as a manager with legal status in accordance with the Decree of the Headman Nglanggeran Village. It's management is semi-modern because already using the technology, there is also a system of profit sharing to the village and District Locally-generated revenue via Village Locallygenerated revenue obtained from retribution withdrawal. In outline, Nglanggeran Tourism Village implementing the concept of community based eco-tourism, while the Pentingsari Tourism Village implementing the concept of community-based rural tourism.

\section{9 limplications findings against theories}

From the comparison above, it can be identified the indicators for identifying the characteristics of community based tourism.

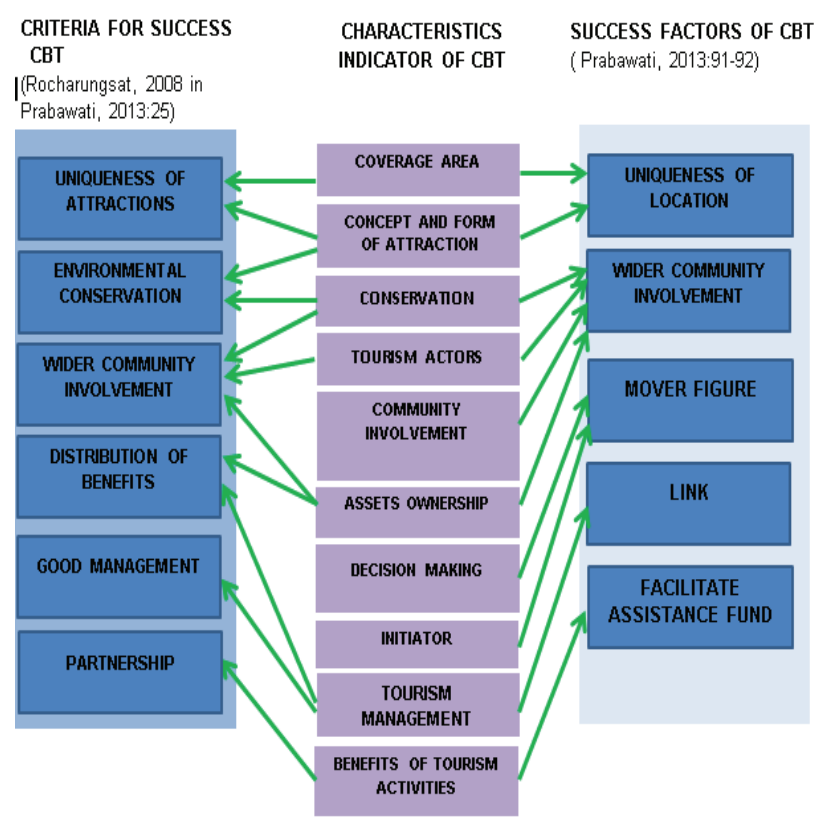

Fig. 8. Success Factors of CBT
These indicators include: Coverage Area; Concepts and Forms of Attraction; Tourism Actors; Involvement and Community Involvement; Benefits of Tourism Activity; Tourism Management; Decision Making; Tourism Asset Ownership; Initiator; Legality of Manager; and Conservation.

\section{Conclusion}

Identifying the characteristics of community based tourism require several indicators. In this study, it is obtained the indicator characteristics that can be used, among other things: covered area; the concept of attraction; forms attractions; tourism actors; community involvement; initiator; forms of community involvement; the benefits of tourism activities; tourism management; decision-making; tourism asset ownership; legality manager; and forms of conservation.

From the comparison using these indicators, it was obtained two characteristics of community based tourism which was found in both tourism village. These characteristics include:

1. The first characteristic is a community-based rural tourism which appeared on Pentingsari Tourism Village. This characteristic covered one hamlet of case study, which will be managed independently by local communities. Government interventions in tourism activities do not dominate. It can be seen from the Tourism Village Board, who belong to the social communities. As the covered area is not wide, local people are able to manage the area more independently. These characteristics prioritize the principle of local wisdom which relates to the main attractions formed by the creativity and habits of people.

2. The second characteristic is a community based eco-tourism which appeared on Nglanggeran Tourism Village. This characteristic covered one village of case study where the influence of governmental in this village is potentially high. It can be seen from the manager of Tourism Village through Pokdarwis formed by BUMDes. Government influence can be seen also from the profit-sharing system and the withdrawal of levy into local government policy. With wide regional coverage (one village), then the people involved even more opportunities for involvement of other parties. These characteristics promote conservation, it relates to the main attractions in the form of natural potential that needs to be preserved.

3. Basic differences between two characteristics of community based tourism at the Nglanggeran and Pentingsari Tourism Village are related to the covered area, the main attractions and the concept from the tourism activities. It will affect the policies and the form of government intervention. It also affects the mindset of local people as tourism actors managing the tourism activities. In addition, the concept presented by the attraction will affect the 
duration of lenght visit to visitors and relate to the concept of tourism.

\section{Acknowledgements}

The authors are very grateful to DRPM DIKTI Kemenristekdikti RI, Indonesia, that has been generously funded the research of this article. The authors are also sincerely thank for all crews of Pentingsari Tourism Board and Pokdarwis Nglanggeran for sharing information with us during the course of this research and the facilitation from the Department of Urban and Regional Planning, Faculty of Engineering, Diponegoro University, Indonesia, which has made the research possible and well completed.

\section{Reference}

1. S. Asker, L. Boronyak, N. Carrard, and M.Paddon, Effective Community Based Tourism. (HengMui Keng Terrace, Singapore: Sustainable Tourism Cooperative Research Centre.2010).

2. Creswell, W. John. Pendekatan Kualitatif, Kuantitatif dan Mixed. Terjemahan Achmad Fawaid. (2010).

3. R. Denman, Guidelines for community-based ecotourism development. Report, (July), 1-24. (2001).

4. C. R. Goeldner, and J. R. B. Ritchie, Tourism Principles, Practice, Philosophies (Eleventh). 58.(New Jersey: John Wiley \& Sons, Inc.2009).

5. S. S. Gumelar, Konsep Pemberdayaan Masyarakat
Berbasis Pariwisata (Community Based Tourism), 1-17. (not publish)

6. S. S. Hadiwijoyo, Perencanaan Pariwisata Perdesaan Berbasis Masyarakat (Sebuah Pendekatan Konsep).(2012).

7. H. Job, and F. Paesler, Journal of Outdoor Recreation and Tourism. 1-2. 18-28.(2013).

8. T. López-guzmán, and S. Sánchez-cañizares, Spring, 6(1), 69-84. (2011).

9. I. Muallisin, Jurnal Penelitian Bappeda Kota Yogyakarta, 2, 15-23. (2007

10. Pokdarwis Nglanggeran. Laporan Akhir PNPM Mandiri Pariwisata 2013 di Kawasan Ekowisata Gunung Api Purba dan Desa Wisata Nglanggeran. (not publish).

11. H. J. P. Prabawati, Faktor-Faktor Keberhasilan Community Based Tourism Dalam Pengembangan Desa Wisata (Studi Kasus:PNPM Mandiri Pariwisata di Dataran Tinggi Dieng). (not publish)

12. N. Purbasari, and A. Manaf, Jurnal Magister Pembangunan Wilayah Dan Kota. 13.100113.(2017)

13. K. W. Sproule, Yale F\&ES Bulletin, 99, 233-250. (1996)

14. P. Suansri, Community Based Tourism: Principles and Meaning. 14. (Bangkok: Responsible Ecological Social Tours Project.2003).

15. S. Warpani, and I. Warpani, Pariwisata Dalam Tata Ruang Wilayah. 23.( Bandung: Institut Teknologi Bandung.2007) 